\title{
IMPLEMENTASI PERLINDUNGAN HUKUM HAK CUTI HAID TERHADAP PEKERJA PEREMPUAN (STUDI PADA PT. BALI CAMEL SAFARIS'S)*
}

\author{
Oleh: \\ Ni Made Rai Meisiani** \\ I Nyoman Suyatna*** \\ Program Kekhususan Hukum Bisnis, \\ Fakultas Hukum, Universitas Udayana
}

\begin{abstract}
ABSTRAK
Semakin pesatnya pembangunan nasional di berbagai sektor berimplikasi terhadap terbukanya lapangan pekerjaan. Melalui ketersediaan lapangan pekerjaan ini mendorong tenaga kerja lakilaki maupun tenaga kerja perempuan untuk bekerja. Perempuan memiliki sedikit keunikan tersendiri yaitu mengalami masa haid setiap bulannya, yang mewajibkan setiap perusahaan memberikan cuti haid. Permasalahan yang diangkat dalam penulisan ini adalah Implementasi Perindungan Hukum Hak Cuti Haid Bagi Pekerja Perempuan pada PT Bali Camel Safaris's. Dalam Penelitian ini menggunakan Metode penelitian empiris.

Berdasarkan penelitian yang telah dilakukan pada PT. Bali Camel Safari's, diketahui bahwa pelaksanaan pemberian cuti haid pada perusahaan tersebut belum dilaksanakan dengan baik berdasarkan Pasal 81 ayat (1) dan Ayat (2) Undang-Undang Nomor 13 Tahun 2003 Tentang Ketenagakerjaan. Sistem penerapannya bukan dalam bentuk cuti melainkan dalam bentuk izin sakit, sehingga jatah libur setiap satu kali dalam minggu dipakai sebagai penggantinya. Hal ini hanya berlaku terhadap pekerja tetap saja, sedangkan pekerja tidak tetap tidak diberikan cuti haid sama sekali. Hal tersebut disebabkan karena ada beberapa faktor yang menjadi penghambat dalam pelaksanaan pemberian cuti haid ini yaitu, terbatasnya pekerja yang bekerja, sulitnya membuktikan benar atau tidaknya pekerja dalam masa haid serta adanya kecemburuan sosial antar pekerja terhadap pemberian cuti haid tersebut. Dalam mengatasi hal tersebut perlu adanya upaya yang

* Penulisan ini berjudul Implementasi Perlindungan Hukum Hak Cuti Haid Terhadap Tenaga Kerja Perempuan (Studi Pada PT. Bali Camel Safari's), yang merupakan makalah ilmiah di luar ringkasan skripsi.

** Penulis pertama dalam penulisan makalh ilmiah ini ditulis oleh Ni Made Rai Meisiani, meru pakan mahasiswa Fakultas Hukum Universitas Udayana, Korespondensi: raimeisiani26@gmail.com.

*** Penulis kedua dalam penulisan makalah ilmiah ini ditulis pleh Dr. I Nyoman Suyatna, SH., MH., selaku Pembimbing Akademik dari penulis pertama di Fakultas Hukum Universitas Udayana.
\end{abstract}


diberikan dari perusahaan. Pada PT. Bali Camel Safari,s melakukan upaya mengatasi hal tersebut dengan memberikan jaminan kesehatan berupa kartu BPJS Kesehatan yang dapat digunakan secara gratis, sehingga perusahaan dapat mengetahui kondisi kesehatan pekerjanya dan mempermudah pemberian cuti haid kepada pekerja perempuannya.

\title{
Kata Kunci: Perlindungan Hukum, Tenaga Kerja Perempuan, Cuti Haid
}

\begin{abstract}
The more rapid national development in various sectors has implications for the opening of jobs. Through the availability of jobs, it encourages male and female workers to work. Women have their own unique characteristics, namely experiencing menstruation each month, which requires every company to give menstruation leave. The problem raised in this paper is the Implementation of the Legal Protection of Menstrual Leave Rights for Women Workers at PT Bali Camel Safaris's. In this study using empirical research methods.

Based on research conducted at PT. Bali Camel Safari's, it is known that the implementation of menstruation leave for these companies has not been implemented properly based on Article 81 paragraph (1) and Paragraph (2) of Law Number 13 Year 2003 concerning Labor. The application system is not in the form of leave but in the form of a sick permit, so that the vacation allowance is used every time in a week. This only applies to permanent workers, while non-permanent workers are not given menstruation leave at all. This is because there are several factors that become obstacles in the implementation of menstruation leave, namely, the limited number of employees who work, the difficulty of proving whether or not workers are in their menstrual period and the existence of social jealousy between workers towards giving menstruation leave. In overcoming this matter, efforts need to be given from the company. At PT. Bali Camel Safari, an effort to overcome this problem by providing health insurance in the form of a Health BPJS card that can be used free of charge, so that the company can know the health conditions of its workers and facilitate the provision of menstruation leave to female workers.
\end{abstract}

\section{Keywords: Legal Protection, Famale Labour, Leave of Absence Menstruation}

\section{Pendahuluan}

\subsection{Latar Belakang Masalah}

Dewasa ini di Indonesia pergerakan pembangunan nasional semakin pesat dan meluas mulai dari pusat hingga menuju ke 
daerah-daerah. Hal ini ditandai dengan mulai berkembangnya potensi-potensi di berbagai sektor yang dimiliki oleh setiap daerah. Dengan semakin pesatya perkembangan di setiap sektor ini dapat membuka luas lapangan pekerjaan bagi masyarakat khususnya warga Indonesia untuk bekerja, sehingga tenaga kerja yang dibutuhkan pun semakin banyak. Dengan banyaknya tenaga kerja yang dibutuhkan tidak menutup kemungkinan bagi kaum perempuan untuk bekerja karena pada dasarnya setiap manusia berhak untuk memiliki pekerjaan. Hal ini diatur pada ketentuan Pasal 27 ayat (2) UUD NRI Tahun 1945 yang mengatur bahwa "Tiap-tiap warga Negara berhak atas pekerjaan dan penghidupan yang layak bagi kemanusiaan".

Secara lahiriah, kaum perempuan dengan kaum laki-laki memang jauh berbeda begitu juga soal pekerjaan. Kebanyakan orang beranggapan bahwa laki-lakilah yang bekerja mencari nafkah sedangkan kaum perempuan hanya menjadi ibu rumah tangga saja. Perbedaan fungsi dan peran serta tanggung jawab antara laki-laki dan perempuan masih menjadi topik permasalahan di masyarakat sampai saat ini yang kerap menjadi penyebab terjadinya diskriminasi gender. Kaum perempuan sebagai warga Negara maupun sebagai sumber daya insani pembangunan, mempunyai kedudukan, hak dan kewajiban, serta kesempatan yang sama dengan laki-laki untuk berperan dalam di segala bidang dan tingkatan. ${ }^{1}$ Kaum perempuan pada dasarnya memiliki keunikan tersendiri yang tidak dimiliki oleh kaum lakilaki baik dari segi fisik, psikis, maupun biologis. Kaum perempuan

1I Made Udiana, I Ketut Westra, dan Ni Ketut Sri Utari, 2015, Kewajiban Pengusaha Menyediakan Angkutan Antar Jemput Bagi Pekerja/Buruh Perempuan Yang Berangkat Dan Pulang Pada Malam Hari di Bali Safari And Marine Park, Jurnal Magister Hukum Udayana Volume 4 No. 3, Fakultas Hukum Universitas Udayana, h. 567 
memiliki siklus sistem reproduksi yang di alamin setiap sebulan sekali yaitu haid. Haid adalah perdarahan pada rahim yang terjadi setiap satu bulan sekali dan merupakan satu kriterium dari wanita normal. ${ }^{2}$ Pada saat masa mestruasi (haid) rata-rata wanita mengalami $10 \%$ penurunan pada kapasitas daya tahan kesabaran dan pekerjaannya. ${ }^{3}$ Haid yang terjadi terutama pada wanita yang memiliki siklus yang tidak normal, sering disertai dengan rasa sakit yang menyebabkan wanita tidak mampu melakukan tugasnya.

Hubungan tenaga kerja dan majikan adalah hubungan hukum yang melahirkan hak dan kewajiban pribadi dalam hidup bermasyarakat. ${ }^{4}$ Dalam Undang-Undang Nomor 13 Tahun 2003 Tentang Ketenagakerjaan menjadi payung hukum bagi perlindungan tenaga kerja bahwa setiap tenaga kerja mempunyai hak dan kesempatan yang sama untuk memperoleh pekerjaan dan penghidupan yang layak tanpa membedakan jenis kelamin, suku, ras, agama, dan aliran politik sesuai dengan minat dan kemampuan tenaga kerja yang besangkutan. Terlebih lagi untuk tenaga kerja perempuan. Selain itu di Dalam International Convention on Elimination of All Forms of Discrimation Againts Women pula diatur mengenai perlindungan sistem reproduksi bagi tenaga kerja perempuan.

Hak cuti haid diatur pada Pasal 81 ayat (1) Undang-Undang Nomor 13 Tahun 2003 yang mengatur bahwa "Pekerja/buruh perempuan yang dalam masa haid merasakan sakit dan memberitahukan kepada atasan, tidak wajib bekerja pada hari

\footnotetext{
2Sama'mur, 2009 P.K., Higene Perusahaan dan Kesehatan Kerja, Gunung Agung, Jakarta, h.142.

${ }^{3}$ A.M. Sugeng Budiono, 2003, Bunga Rampai Hiperker dan Kesehatan Kerja, Universitas Diponegoro, Semarang, h. 147.
} 
pertama dan kedua pada waktu haid". Serta Peraturan Pemerintah Republik Indonesia Nomor 78 Tahun 2015 Tentang Pengupahan diatur pada Pasal 24 Ayat (3) huruf b yang mengatur "Pekerja/Buruh perempuan yang sakit pada hari pertama dan kedua masa haidnya sehigga tidak dapat melakukan pekerjaannya;". Prinsip yang terkandung dalam ketentuan konstitusional di atas berkaitan erat dengan upaya perlindungan bagi tenaga kerja. ${ }^{5}$

Kemudian masalah yang mencul dengan adanya cuti haid ini bahwa tidak semua kaum perempuan yang sedang dalam masa haid merasakan sakit. Hal tersebut menimbulkan adanya kemungkinan pekerja yang curang untuk bolos bekerja, karena sulit membuktikan bahwa seseorang sedang mengalami masa haid maka kebanyakan perusahaan tidak memberikan pekerjanya untuk mengambil cuti haid. Selain itu masih banyak juga pekerja yang tidak tahu akan adanya aturan penerapan cuti haid tersubut.

Berdasakan hal tersebut, maka penulis tertarik untuk membuat penelitian dengan judul "Implementasi Perlindungan Hukum Hak Cuti Haid Terhadap Pekerja Perempuan (Studi Pada PT. Bali Camel Safaris's)"

\subsection{Tujuan}

1. Untuk mengetahui pelaksanaan pemberian cuti haid bagi pekerja perempuan di PT. Bali Camel Safari's

2. Untuk mengetahui kendala-kendala diterapkannya hak cuti haid pada pekerja perempuan dan mengetahui

${ }^{4}$ Udiana I Made, 2018 Industrialisasi \& Tanggungjawab Pengusaha Terhadap Tenaga Kerja Terlibat Hukum, Udayana University Press, Denpasar, h.27.

5 Udiana Made, 2015, Kedudukan dan Kewenangan Pengadilan Hubungan Industrial, Udayana University Press, Denpasar, h. 4. 
tindakan dan upaya yang dapat dilakukan oleh PT. Bali Camel Safari's.

\section{Isi Makalah}

\subsection{Metode Penelitian}

Metode yang digunakan dalam penelitian ini adalah metode penelitihan hukum empiris. Penelitian empiris diteliti dari sifat hukum yang nyata sesuai dengan kenyataan yang hidup di dalam masyarakat. Jadi, penelitian empiris harus dilakukan di lapangan dengan mnggunakan Metode teknik lapangan. ${ }^{6}$ Metode pendekatan dalam penelitian ini menggunakan penelitian yuridis sosiologis. Pendekatan yuridis sosiologis adalah pendekatan yang didasarkan pada peraturan perundang-undngan yang dapat ditinjau menggunakan teori hukum dan melihat kenyataan yang ada di lapangan yakni terkait dengan fenomena hukum tentang terjadinya kesenjangan antara norma dengan perilaku masyarakat (kesenjangan antara das sollen dan das sein), mengenai pelaksanaan cuti haid bagi pekerja perempuan di PT. Bali Camel Safari's Kecamatan Kuta Selatan.

\subsection{Hasil dan Pembahasan}

\subsubsection{Pelaksanaan Perlindungan Hukum Atas Hak Cuti Haid Terhadap Pekerja Perempuan di PT Bali Camel Safari's}

Tenaga kerja merupakan salah satu faktor yang penting dalam suatu pembangunan. Pembangunan yang terus berkembang memberikan kesempatan tenaga kerja perempuan untuk bekerja begitu pula dengan PT. Bali Camel Safari's yang membuka kesempatan kerja bagi tenaga kerja perempuan. PT. Bali

6 H. Hilman, 1995, Metode Pembuatan Kertas Kerja dan Sripsi Ilmu Hukum, Cet. I, Mandar Maju, Bandung,. h.62. 
Camel Safaris's merupakan perusahan yang bergerak dibidang pariwisata yaitu wisata naik unta dan foto prewedding yang berkedudukan di Kecamatan Kuta Selatan. Kaum perempuan memang memiliki perbedaan tersendiri yaitu kaum wanita dikenal sangat lembut dan ramah dalam bertutur kata dari pada kaum laki-laki. Jika dibandingkan dengan kaum laki-laki, kaum perempuan lebih teliti dan sabar dalam bekerja. ${ }^{7}$ Perlindungan hukum bagi tenaga kerja utamanya terhadap tenaga kerja perempuan agar hak-hak dasar pekerja, mendapat perlakukan yang sama tanpa diskriminasi atas dasar apapun dapat terjamin dengan tetap melihat perkembangan kemajuan dunia usaha. ${ }^{8}$ Perlindungan Hukum Timbul karena adanya suatu hubungan hukum. Hubungan hukum merupakan interaksi antara subjek hukum yang mempunyai relevansi hukum atau akibat hukum yaitu timbulnya hak dan kewajiban. ${ }^{9}$ Perlindungan tenaga kerja telah diatur dalam Undang-Undang Nomor 13 Tahun 2003 Tentang Ketenagakerjaan. Tidak hanya itu didalam UndangUndang ini juga terdapat ketentuan yang secara khusus mengatur tentang hak pekerja perempuan yaitu hak cuti haid yang tercantum palam ketentuan pasal 81 yang mengatur:

“(1) Pekerja/buruh perempuan yang dalam masa haid merasakan sakit dan memberitahukan kepada pengusaha, tidak wajib bekerja pada hari pertama dan kedua pada waktu haid.

(2) Pelaksanaan ketentuan sebagaimana dimaksud dalam ayat (1) diatur dalam perjanjian kerja, peraturan perusahaan, atau perjanjian kerja bersama".

7 Putu Angga Pratama Suksma, 2016, Hak Khusus Tenaga Kerja Wanita Dalam Memberikan Asi Eksklusif Di Provinsi Bali, Jurnal Magister Hukum Udayana, Volume 5 No. 1, Fakultas Hukum Universitas Udayana, h. 163.

8 Asri Wijayanti, 2010, Hukum Ketenagakerjaan Pasca Reformasi, Sinar Grafika, Jakarta, h.6

${ }^{9}$ Soeroso, 2006, Penghantar Ilmu Hukum, Cetak Kedelapan, Sinar Grafik, Jakarta, h.49. 
Selain berdasarkan pada Undang-Undang Nomor 13 Tahun 2003 tentang Ketenagakerjaan, pelaksanan perlindungan hukum hak cuti haid juga mengacu pada Peraturan Pemerintah Republik Indonesia Nomor 78 Tahun 2015 Tentang Pengupahan yaitu ketentuan Pasal 24 Ayat (3) huruf b yang mengatur: "Pekerja/buruh perempuan yang sakit pada hari pertama dan kedua masa haidnya sehingga tidak dapat melakukan pekerjaan".

Di dalam ketentuan Pasal 1 Angka (1) Undang-Undang Nomor 39 Tahun 1999 tentang Hak Asasi Manusia, memberikan rumusan tentang pengertian Hak Asasi Manusia sebagi berikut:

"Seperangkat hak yang melekat pada hakikatnya dan keberadaan manusia sebagai makhluk Tuhan Yang Maha Esa dan merupakan anugerah-Nya yang wajib dihormati, dijunjung tinggi dan dilindungi oleh Negara, hukum, pemerintah, dan setiap orang demi kehormatan serta perlindungan harkat dan martabat manusia".

Berdasarkan ketentuan-ketentuan yang disebutkan diatas bahwa pemerintah memberikan perlindungan hukum bagi pekerja perempuan mengenai hak cuti haid. Perlindungan pekerja dapat dilakukan dengan jalan memberikan tuntunan, maupun dengan jalan meningkatkan pengakuan hak-hak asasi manusia, perlindungan fisik dan teknis, serta social ekonomi melalui norma yang berlaku dalam lingkungan kerja. ${ }^{10}$ Sehingga perusahan wajib memberikan hak cuti haid bagi pekerja perempuannya. Karena haid merupakan hal kodrati yang wajib dialami oleh perempuan sebelum menginjak masa menopause.

Pada PT. Bali Camel Safari's pemberian gaji pokok pekerjanya berpedoman pada Peraturan Pemerintah Nomor 78 Tahun 20015 Tentang Pengupahan dan berdasarkan UMK Kabupaten Badung Tahun 2018, sebesar Rp. 2.400.000,- serta

10 Zaeni Asyhadie, 2007, Hukum Kerja (Hukum Ketenagakerjaan bidang Hubungan Kerja), PT. Rja Grafindo Persada, Jakarta, h.58. 
pemberian jasa pelayanan (service) yang diberikan secara merata sesuai dengan pemasukan perusahaan setiap bulannya. Untuk pemberian gaji terhadap pekerja tidak tetap menggunakan sistem pengupahan yang diberikan perhari atau dihitung berdasarkan jumlah hari kerja yaitu Rp. 100.000 per harinya. Pekerja pada PT. Bali Camel Safari's bekerja selama 7 jam dan 1 jam istirahat, jika di akumulasikan pekerja bekerja sebanyak 8 jam per hari. Banyak Jumlah Hari kerja setiap pekerja sebanyak 6 hari dalam seminggu yang diserta dengan pemeberian libur 1 kali dalam seminggu dan setiap pekerja tetap mendapat public holiday yang diberikan kepada pekerja sesuai dengan hari besar keagamannya masingmasing. Pekerja tetap yang telah bekerja selama 1 tahun diberikan cuti sebanyak 12 kali setiap tahunnya.

Berdasarkan hasil wawancara tanggal 1 Oktober 2018 dengan Bapak Made Wirata selaku Owner Representatif dari Perusahaan PT. Bali Camel Safari's bahwa hukum yang digunakan oleh PT. Bali Camel Safari's dalam memberikan cuti haid kepada pekerja perempuan yaitu berpedoman kepada Undang-Undang Nomor 13 Tahun 2003 Tentang Ketenagakerjaan serta perjanjian kerja. Melalui wawancara tersebut beliau menyatakan bahwa dalam perjanjian kerja maupun peraturan kerja perususahaan sendiri cuti haid memang tidak diatur, Namun menyadari bahwa pemberian hak cuti haid ini penting diberikan untuk menjamin hak-hak pekerjanya, penerapan hak cuti haid tersebut bukan berupa pemberian cuti yang khusus diberikan kepada pekerja perempuan setiap bulannya, tetapi berupa ijin sakit dan tetap digaji bagi tenaga kerja tetap. Sistem pemberian cuti haid ini diberikan apabila pekerja yang hendak cuti haid menyertakan surat keterangan dari dokter. Namun cuti haid tersebut hanya diberikan sebanyak 2 hari saja, jika pekerjanya cuti melebih dua 
hari maka akan dipotong liburnya dalam satu minggu dan atau cuti tahunan yang dimiliki oleh pekerjanya tersebut. Kemudian jika dalam ijin sakit ini pekerja tidak dapat menyertakan surat keterangan dokter maka libur dan cuti yang dimiliki oleh pekerja yang bersangkutan digunakan sebagi penggantinya. Hal ini dilakukan untuk menghindari kecemburuan sosial antar pekerja khususnya pekerja laki-laki. Serta kerugian yang dapat ditimbulkan seperti, pekerjaan yang terbengkalai akibat berkurangnya pekerja yang bekerja dan menghindari kecurangan pekerja yang berniat untuk bolos bekerja dengan adanya cuti haid tersebut.

Berdasarkan hasil penelitian Pada perusahan PT. Bali Camel Safari's, pekerja perempuannya belum memahami betul makna cuti haid. Mereka menyatakan bahwa tidak tahu akan adanya hak cuti haid. Bahkan beberapa dari mereka tidak mengetahui tentang adanya Undang-Undang Ketenagakerjaan. Berdasarkan hasil wawancara dengan Ibu Lely sebagai salah satu pekerja tetap di PT. Bali Camel Safari's terhadap pelaksanaan cuti haid bahwa beliau tidak pernah melakukan cuti haid sebelumnya. Biasanya bila dalam masa haid beliau akan tetap bekerja seperti biasa. Menurut beliau cuti haid itu juga tidak begitu penting dan terkesan ribet karena harus disertai dengan surat keterangan dokter. Jika masih bisa bekerja lebih baik tetap bekerja, sehingga pekerjaan menjadi cepat selesai. Tetapi jika beliau merasa sakit beliau akan meminta izin untuk istirahat dirumah dengan alasan tidak enak badan. Menurut beliau sedikit tidak enak (malu) mengatakan bahwa izin karena haid sehingga menurut beliau tidak perlu untuk dinyatakan. Perusahan akan tetap mengizinkan namun dengan menyertakan surat keterangan dokter. Hal ini dapat dilakukan apabila memungkinkan, karena melihat kondisi dilapangan 
pekerja yang bekerja di PT. Bali Camel Safari's juga tergolong sedikit.

Berbeda dengan pekerja tetap penerapan hak cuti haid ini tidak diterapkan terhadap tenaga kerja yang tidak tetap yang pemberian upahnya berupa upah harian. Jadi, jika tidak bekerja maka tidak digaji, sehingga dapat disimpulkan perusahaan tidak memberikan hak pada pekerja tidak tepat untuk cuti haid. Hal ini dikarenakan pekerja harian tidak memiliki kontrak kerja dengan perusahaan sehingga hak-haknya pun dibatasi. Bagi perusahaan untuk memeriksa apakah pekerjanya benar-benar dalam masa haid sangat sulit dibuktikan. Mengingat surat keterangan sakit pun di jaman sekarang sangat mudah dimanipulasi. Untuk menghindari kerugian PT. Bali Camel Safari's hanya menerapkan cuti haid ini kepada pekerja tetap saja dengan ketentuanketentuan yang harus dipenuhi.

Selain PT Bali Camel Safari's penerapan cuti haid juga belum berjalan dengan baik di usaha-usaha di Kecamatan Kuta Selatan yang telah diteliti, yang sama-sama bergerak dibidang pariwisata yaitu Villa dan Hotel. Villa dan Hotel di Kuta Selatan memang memiliki karyawan tergolong banyak. Salah satu hotel yang diteliti yaitu Swiss BellHotel Segara. Hotel ini memiliki 110 pekerja yang 30\% pekerjanya adalah perempuan. Berdasarkan wawancara yang dilakukan dengan Bapak Ahmad selaku Asistant Human Resources, beliau menyatakan bahwa di dalam hotel tersebut cuti haid tidak diatur baik dalam peraturan hotel maupun perjanjian kerja. Dalam perusahaan tersebut hanya diterapkan izin sakit tidak bekerja tetapi dengan surat keterangan dokter, hal ini diterapkan baik itu karyawan tetap maupun tidak tetap. 
Kemudian salah satu Villa yang telah diteliti penerapan cuti haid tenaga kerja perempuannya yaitu di Villa Vinila. Di Villa Vinila tersebut juga penerapan cuti haidnya tidak berjalan dengan baik karena berdasarkan wawancara yang dilakukan dengan Ibu Tina selaku Operational Manager, bahwa di Villa Vinila tidak memberikan cuti haid kepada pekerja perempuannya, namum memberikan izin sakit dengan surat keterangan dokter.

Berdasarkan penelitian yang dilakukan penerapan cuti haid memang masih belum sesuai dengan Undang-Undang Ketenagakerjaan khususnya pada PT. Bali Camel Safari's Kuta Selatan. Kebanyakan dari perusahan-perusahan tidak mencantumkan ketentuan Pasal 81 Undang-Undang Nomor 13 Tahun 2003 Tentang Ketenagakerjaan baik pada peraturan perusahaan maupun perjanjian kerja. Sehingga perlindungan hukum bagi tenaga kerja perempuan kurang terpenuhi khususnya hak untuk mendapatkan cuti haid.

\subsubsection{Hambatan Dalam Pelaksanaan Perlindungan Hukum Hak Cuti Haid Serta Upaya-Upaya yang Diberikan Oleh PT. Bali Camel Safari's}

Implementasi pelaksanaan pemberian atas hak cuti haid pada PT. Bali Camel Safari's belum berjalan secara efektif, karena masih ada beberapa Kendala dan hambatan dalam pelaksanaanya. Dalam memberikan perlindungan hukum hak cuti haid terhadap pekerja perempuan, terdapat beberpa faktor yang menjadi penghambat dalam pelaksanaan pemberian cuti haid terhadap pekerja perempuan pada PT. Bali Camel Safari's yaitu, baik dari pekerjanya sendiri maupun dari pihak perusahaan. Sebagian besar dari pekerja pada PT. Bali Camel Safaris khususnya perempuan tidak memahami betul makna dari cuti haid tersebut. 
Mereka beranggapan bahwa cuti haid ini bukan hal yang harus dilakukan semasih bisa bekerja. Selain itu haid merupakan suatu yang sedikit memalukan jika di nyatakan, serta pemberian cuti haid yang harus disertai dengan surat keterangan dokter membuat mereka malas untuk mengurusnya. Pemberian cuti haid tersebut hanya berlaku pada pekerja tetap saja, tetapi pekerja tidak tetap hanya diberikan libur tanpa digaji.

Dari perusahan sendiri yang menjadi penghambat pelaksanaan cuti haid ini yaitu sulitnya membuktikan apakah pekerjanya sedang dalam masa haid atau tidak. Maka dari itu PT. Bali Camel Safaris mengupayakannya pemberian fasilitas kesehatan berupa kartu BPJS Kesehatan yang dapat di digunakan oleh pekerja secara gratis. Selain itu untuk mengindari kecemburuan sosial antar pekerja khususnya pekerja laki-laki PT. Bali Camel Safari's hanya memberikan cuti haid kepada pekerja tetapnya saja. Rasa Khawatir akan kerugian yang dialami jika memberikan cuti haid kepada semua pekerja perempuannya baik tetap maupun tidak tetap juga menjadi faktor penghambat dari pelaksanaan cuti haid tersebut. Yang menjadi acuan dari PT Bali Camel Safari's dalam pemberian cuti haid ini berdasarkan ketentuan Pasal 93 ayat (1) dan pasal 93 ayat (2) huruf b UndangUndang Nomor 13 Tahun 2003 Tentang Ketenagakerjaan yang mengatur bahwa: "Upah tidak dibayar apabila pekerja/buruh tidak melakukan pekerjaan". Ketentuan Tersebut ditujuakan kepada pekerja tidak tetap saja. Sedangkan untuk karyawan tetap diatur dalam ketentuan Pasal 93 Ayat 2 (b) bahwa:

"Ketentuan sebagaimana yang dimaksud dalam ayat (1) tidak berlaku, dan pengusaha wajib membayar upah apabila:

(b) Pekerja/Buruh perempuan yang sakit pada hari pertama dan kedua masa haidnya sehingga tidak dapat melakukan pekerjaan." 


\section{Kesimpulan}

Berdasarkan hasil penelitan tesebut, maka dapat ditarik kesimpulan sebagai berikut:

1. Pelaksanaan pemberian hak cuti haid pada PT. Bali Camel Safari,s belum dilaksanakan sesuai dengan UndangUndang Nomor 13 Tahun 2003 Tentang Ketenagakerjaan yang mengacu pada Ketentuan Pasal 81 ayat (1) dan (2), tetapi penerapannya berupa pemberian ijin tidak bekerja dengan surat keterangan dokter. Pemberian hak cuti haid ini hanya diberikan kepada pekerja tetap sedangkan pekerja yang tidak tetap atau sifatnya harian tidak diberikan. Hal ini dikarenakan pekerja harian tidak memiliki kontrak kerja dengan perusahaan sehingga hakhaknya pun dibatasi.

2. Faktor-faktor yang menjadi penghambat dalam pelaksanaan pemberian hak cuti haid yaitu, kurangnya pemahaman pekerja terhadap cuti haid, timbulnya kecemburuan social antar pekerja khususnya pekerja lakilaki, serta kurangnya pekerja yang bekerja di PT.Bali Camel Safari's membuat pekerja tidak mendapat haknya karena faktor tanggungjawab yang dimilki oleh pekerja dalam pekerjaannya yang tidak memiliki pengganti. Berdasarkan hal tersebut upaya-upaya yang dilakukan PT Bali Camel Safari's yaitu penyediaan fasilitas kesehatan berupa kartu BPJS Kesehatan yang disediakan oleh perusahan secara gratis untuk mengetahui kondisi kesehatan karyawannya. 


\section{Daftar pustaka}

\section{Buku}

Asri Wijayanti, 2010, Hukum Ketenagakerjaan Pasca Reformasi, Sinar Grafika, Jakarta.

H. Hilman, 1995, Metode Pembuatan Kertas Kerja dan Sripsi Ilmu Hukum, Cet. I, Mandar Maju, Bandung.

Sama'mur, 2009, P.K,Higene Perusahaan dan Kesehatan Kerja, Gunung Agung, Jakarta.

Soeroso, 2006, Penghantar Ilmu Hukum, Cetak Kedelapan, Sinar Grafik, Jakarta,

Sugeng Budiono, 2003, Bunga Rampai Hiperker dan Kesehatan Kerja, Universitas Diponegoro, Semarang

Udiana I Made, 2018 Industrialisasi \& Tanggungjawab Pengusaha Terhadap Tenaga Kerja Terlibat Hukum, Udayana University Press, Denpasar.

2015, Kedudukan dan Kewenangan Pengadilan Hubungan Industrial, Udayana University Press, Denpasar.

Zaeni Asyhadie, 2007, Hukum Kerja (Hukum Ketenagakerjaan bidang Hubungan Kerja), PT. Rja Grafindo Persada, Jakarta.

\section{Artike1}

I Made Udiana, I Ketut Westra, Ni Ketut Sri Utari, 2015, Kewajiban Pengusaha Menyediakan Angkutan Antar Jemput Bagi Pekerja/Buruh Perempuan Yang Berangkat Dan Pulang Pada Malam Hari di Bali Safari And Marine Park, Jurnal Magister Hukum Udayana Volume 4 No. 3, Fakultas Hukum Universitas Udayana. https://ojs.unud.ac.id/index.php/jmhu/article/view/18064 111731, diaksespada tanggal 19 Maret 2019.

Putu Angga Pratama Suksma, 2016, Hak Khusus Tenaga Kerja Wanita Dalam Memberikan Asi Eksklusif Di Provinsi Bali, Jurnal Magister Hukum Udayana, Volume 5 No. 1, Fakultas Hukum Universitas Udayana. https://ojs.unud.ac.id/index.php/jmhu/article/view/17932 L14463, diaksespada tanggal 19 Maret 2019.

\section{Perundang-Undangan}

Undang-Undang Nomor 13 Tahun 2003 tentang Ketenagakerjaan, Lembaran Negara Republik Indonesia Nomor 39 Tahun 2003, Tambahan Lembaran Negara Republik Indonesia Nomor 4279. 